\title{
Chemical Constituents and Antioxidant Activity of Leaves and Stems Extracts of Monteverdia communis (Celastraceae)
}

\author{
Fernanda Moreira do Amaral 1,*(i), João Marcelo Alvarenga Braga ${ }^{(\mathbb{D})}$, Lorena Diniz Guimarães ${ }^{3(\mathbb{C})}$, \\ Alessandra Leda Valverde ${ }^{4(\mathbb{C})}$, Maria Carolina Anholeti ${ }^{3(\mathbb{D})}$, Selma Ribeiro de Paiva ${ }^{5(\mathbb{D}}$, Ana Joffily 5 (i) \\ 1 Programa de Pós-Graduação em Ciências Biológicas (Botânica), Museu Nacional, Universidade Federal do Rio de Janeiro- \\ UFRJ, Brasil; fer.m.amaral@ gmail.com (F.M.A.); \\ 2 Instituto de Pesquisas Jardim Botânico do Rio de Janeiro, Brasil; jmabraga@jbrj.gov.br (J.M.A.B.); \\ 3 Departamento de Farmácia e Administração Farmacêutica, Faculdade de Farmácia, Universidade Federal Fluminense- \\ UFF, Brasil; lorenadiniz@id.uff.br (L.D.G.); carolanholeti@gmail.com (M.C.A.); \\ 4 Departamento de Química Orgânica, Instituto de Química, Universidade Federal Fluminense-UFF, Brasil; \\ alessandravalverde@id.uff.br (A.L.V.); \\ 5 Departamento de Biologia Geral, Instituto de Biologia, Universidade Federal Fluminense-UFF, Brasil; \\ selmapaiva@id.uff.br (S.R.P.); anajoffily@id.uff.br (A.J.); \\ * Correspondence: fer.m.amaral@gmail.com (F.M.A.);
}

Scopus Author ID 57210289315

Received: 11.05.2021; Revised: 12.06.2021; Accepted: 14.06.2021; Published: 18.06.2021

\begin{abstract}
Species from the genus Monteverdia (Celastraceae) are widely used in traditional medicine for gastric disorders. Pharmacological and phytochemical studies focus on Monteverdia ilicifolia ("espinheira-santa"). Monteverdia communis is endemic and abundant in southeast Brazil, and no previous work was reported in literature involving its chemical aspects. Given the potential of Monteverdia species as sources of natural antioxidants, this work aimed to undertake a chemical study and evaluate the antioxidant activity of leaves and stems extracts of $M$. communis. A fraction enriched with the triterpenes epifriedelinol and 3-oxo-friedelin was isolated from the hexane extract of the leaves. The antioxidant activity of ethanol extracts of leaves and stems was significantly higher than butylated hydroxytoluene (BHT) and statistically equivalent to rutin (positive controls). A weak negative correlation with the total flavonoid content was verified for these extracts, suggesting that the antioxidant activity may be related to the presence of other compounds in addition to flavones and flavonols. The phytochemical screening of hexane and ethanol extracts from leaves and stems revealed their chemical profile, providing quality control data. The results allow the indication of M. communis as a source of bioactive terpenoids and a promising target for further studies to isolate and identify antioxidant compounds.
\end{abstract}

Keywords: epifriedelinol; free radical scavenging; friedelin; medicinal plants; triterpenoids.

(C) 2021 by the authors. This article is an open-access article distributed under the terms and conditions of the Creative Commons Attribution (CC BY) license (https://creativecommons.org/licenses/by/4.0/).

\section{Introduction}

The use of plants for medicinal purposes is millenarian. Studies in Paleobotany envisage the possibility that the man had adopted this practice at least sixty thousand years ago [1]. Besides traditional medicine, plant species for health care remain current through the production and consumption of herbal products. This market moves billions of dollars per year in the world [2]. 
Brazil represents an important scene in the context of medicinal plants. In association with great plant biodiversity, the traditional knowledge is added to a rational search for plant species with a therapeutic value from an expressive cultural diversity [3]. Acknowledging the importance of this relation, the Brazilian Policy and Program of Medicinal Plants and Phytotherapeutics [4] emphasizes the need to promote popular practices for the use of medicinal plants by the population, as well as to assure safety, efficacy and quality of access to herbal medicines.

Monteverdia A. Rich. is a tropical lineage of Maytenus Mol. s.l. (Celastraceae), comprising 123 species [5,6], of which 48 occur in Brazil and 35 are endemic [7,8]. In traditional medicine, the treatment of gastric disorders is highlighted in the genus, and the pharmacological and phytochemical studies in the literature are focused on Monteverdia ilicifolia (Mart. ex Reiss.) Biral [9]. This species is known as "espinheira-santa" (holy spines) [10], and usually found in formal and informal trade in Brazil [11-13].

Extracts of M. ilicifolia show high antioxidant activity, attributed to the presence of phenolic compounds $[14,15]$. Natural antioxidants are an object of great interest to the scientific community, given their mechanisms to prevent several diseases [16]. In the genus, other species demonstrate antioxidant properties, such as Monteverdia aquifolia (Mart.) Biral [17,18], Monteverdia dasyclada (Mart.) Biral [19], Monteverdia imbricata (Mart. ex Reiss.) Biral [20], Monteverdia krukovii (A.C.Sm.) Biral [21] and Monteverdia obtusifolia (Mart.) Biral [22].

Medicinal plants with canonical use, such as M. ilicifolia, are often overexploited, leading to a demographic reduction in their natural populations and genetic diversity loss [2325]. Therefore, the search for alternatives to those species represents a reasonable option for lessening biodiversity pressure and contributing to its rational use.

Monteverdia communis (Reiss.) Biral is endemic of Brazil and abundant in the southeast region, found as shrubs and trees $[7,8,26]$. Differently from "espinheira-santa", the leaves are not spined, and their morphology was described by Joffily and Vieira (2005) [27].

Given the potential of Monteverdia species as sources of natural antioxidants and the great abundance of $M$. communis in Brazil, this work aimed to undertake chemical study and evaluate the antioxidant activity of compounds present in leaves and young stems of the species since there is no previous work reported in literature involving its chemical aspects.

\section{Materials and Methods}

\subsection{Chemicals and equipment.}

All solvents, reagents, and adsorbents used in this work were of analytical grade and obtained from Merck, Vetec, and Sigma-Aldrich. DPPH (1,1-diphenyl2-picrylhydrazyl) free radical and rutin were purchased from Sigma and commercial BHT (butylated hydroxytoluene) from Purifarma. Measurements were obtained using a UV-VIS spectrometer Biospectro SP220. The analysis was performed on an Agilent model $6890 \mathrm{~N}$ gas chromatography equipped with a mass selective detector, model 5973N.

\subsection{Plant material.}

For the present study, leaves and young stems of M. communis were collected in "Mata do Entorno", an interior of dense and dry forest between neighborhoods of Gávea and Horto, municipality of Rio de Janeiro, State of Rio de Janeiro, Brazil, in December 2011. The plant 
material was registered in the herbarium collection of the Instituto de Pesquisas Jardim Botânico do Rio de Janeiro, Brazil (J.M.A.Braga, 11-002 - RB811236). This species' study is part of a project duly registered in the Genetic Heritage Management Council System A511EB8.

\subsection{Preparation of crude extracts.}

Leaves and stems were separated, dried in an oven at $40{ }^{\circ} \mathrm{C}$ and reduced to small fragments using a processor. Hexane and ethanol extracts of leaves and stems were obtained by static maceration of the plant organs with the respective solvents, followed by successive solvent renewals and evaporation under reduced pressure in a rotary evaporator, leading to obtaining four crude extracts.

\subsection{Isolation and identification of compounds.}

The crude hexane extract of the leaves was solubilized in chloroform, leading to the spontaneous precipitation of crystals. The precipitate was pre-purified by rinsing with acetone and then fractionated by silica gel column chromatography, using as eluents hexane, ethyl acetate, and methanol in increasing polarity gradient. A total of 107 fractions were obtained, regrouped in nine fractions after analysis by thin-layer chromatography. Silica gel was used as a stationary phase, a 10\% ethyl acetate/hexane solution as mobile phase, and anisaldehyde and sulfuric acid solutions as derivatization agents.

Fraction 9 was analyzed by thin-layer chromatography, compared with pre-existing laboratory samples containing terpenoids patterns [28], and submitted to gas chromatography coupled to mass spectrometry (GC-MS). A volume of $1 \mu \mathrm{L}$ of the solution was injected at a concentration of $1 \mathrm{mg} / \mathrm{mL}$. The following conditions were used: helium as the carrier gas, flow rate $2.0 \mathrm{mLmin}-1$, injector temperature $300^{\circ} \mathrm{C}$, and ion source temperature $230^{\circ} \mathrm{C}$. The oven temperature was programmed from $150-300^{\circ} \mathrm{C}$ at $10^{\circ} \mathrm{C}$ min- 1 and held at $300^{\circ} \mathrm{C}$ for $15 \mathrm{~min}$. The sample injection volume was $1 \mu \mathrm{L}$. The mass spectra were analyzed and compared with the equipment database (Wiley) and literature data to identify its chemical constituents.

\subsection{Antioxidant activity.}

Antioxidant activity of fraction 9 and hexane and ethanol extracts of leaves and stems of $M$. communis, was assessed by a spectrophotometric method based on scavenging of the free radical DPPH (1,1-diphenyl2-picrylhydrazyl), according to the methodology described by Silva and Paiva (2012) [29]. BHT (butylated hydroxytoluene) and rutin (a flavonol heteroside) were used as positive controls.

Solutions concentrated at 250,125, 50,25, 10 and $5 \mu \mathrm{g} / \mathrm{mL}$ in methanol were prepared for each sample and the positive controls BHT and rutin. Aliquots of $2.5 \mathrm{~mL}$ of each solution (sample or controls) in all concentrations were mixed in a vortex agitator with $1.0 \mathrm{~mL}$ of a solution of $0.3 \mathrm{mM}$ DPPH in methanol. As a negative control, the sample (or control) was substituted with methanol. The analysis was performed with three independent assays, in triplicate, except BHT, for which it was performed only two experiments in triplicate. The absorbances were read in a spectrophotometer at $518 \mathrm{~nm}$ every 5 minutes during 30 minutes of reaction.

The absorbance values were used to calculate the total antioxidant activity, determined as the $\mathrm{EC}_{50}$ in $\mathrm{g}$ sample / $\mathrm{g} \mathrm{DPPH}$, representing the sample's concentration required to reduce 
the initial concentration of DPPH in $50 \%$. The result $\left(\mathrm{EC}_{50}\right)$ was expressed as the mean \pm standard deviation of three independent experiments carried out for each sample. The comparison among the means was performed using a one-way analysis of variance (ANOVA). Ultimately, the assessment of antioxidant activity of samples of $M$. communis was carried out by comparing their $\mathrm{EC}_{50}$ values with the ones obtained for the positive controls and among each other, also using ANOVA.

\subsection{Total flavonoids content.}

The total flavonoids content was expressed as flavones and flavonols and determined in the ethanol extracts of leaves and stem using a colorimetric method involving reaction with aluminum chloride [29], using $20 \mathrm{mg}$ of each extract $(8 \mathrm{mg} / \mathrm{mL})$ for the preparation of samples, and rutin as a standard $(1 \mathrm{mg} / \mathrm{mL}$ for the preparation of samples). Statistical comparison among the percentages obtained in triplicate was performed by ANOVA and results were expressed as mean \pm standard deviation.

Pearson's correlation test was used to evaluate the possible correlation between the total antioxidant activity of the ethanol extracts $\left(\mathrm{EC}_{50}\right)$ and the percentages of flavonoids.

\subsection{Phytochemical screening.}

The crude extracts were solubilized in the proportion of $1 \mathrm{mg} / 1 \mathrm{~mL}$ of methanol and submitted to specific tests for several metabolites classes [30]. Each sample was dripped onto a filter paper strip to verify the presence of phenolic compounds, flavonoids, coumarins, triterpenes, and steroids. For tannins, anthraquinones, alkaloids and saponins, aliquots of the samples were placed in test tubes. Specific reagent solutions were added to the samples (Table 1). The test tube was shaken vigorously in the saponins test for a few minutes and incubated.

Table 1. Chemical classes assessed and the respective reagents used in the phytochemical screening of crude extracts of Monteverdia communis.

\begin{tabular}{c|c} 
Chemical Class & Reagent Solution \\
\hline Phenolic compounds & $2 \% \mathrm{FeCl}_{3}$ \\
\hline Flavonoids & $5 \% \mathrm{AlCl}_{3}$ \\
\hline Tannins & $2.5 \%$ gelatin with $10 \% \mathrm{HCl}$ \\
\hline Anthraquinones & $0.5 \mathrm{M} \mathrm{NaOH}$ \\
\hline Coumarins & $10 \% \mathrm{KOH}$ \\
\hline Saponins & $2 \mathrm{ml}$ of distilled water \\
\hline Triterpenoids and Steroids & Acetic anhydride and concentrated sulfuric acid \\
\hline Alkaloids & Dragendorff
\end{tabular}

\section{Results and Discussions}

\subsection{Extractive yields.}

Preparation of crude extracts of leaves and stems of $M$. communis led to the extractive yields showed in Table 2.

Table 2. Extraction yields from leaves and stems of Monteverdia communis.

\begin{tabular}{c|c|c|c|c} 
Plant organ & Dry weight & Solvent & Extract weight & Extractive yields \\
\hline Leaves & $472.82 \mathrm{~g}$ & Hexane & $3.186 \mathrm{~g}$ & $0.67 \%$ \\
\hline & & Ethanol & $8.296 \mathrm{~g}$ & $1.75 \%$ \\
\hline Stems & $254.52 \mathrm{~g}$ & Hexane & $2.330 \mathrm{~g}$ & $0.92 \%$ \\
\hline & & Ethanol & $8.270 \mathrm{~g}$ & $3.25 \%$
\end{tabular}


Extraction with ethanol demonstrated yields 2.6 times higher than with hexane in leaves and 3.5 times higher in stems.

\subsection{Isolation and Identification of Compounds.}

Fractionation of the precipitate $(845 \mathrm{mg})$ obtained from the hexane crude extract of leaves led to the isolation of fraction $9(450 \mathrm{mg})$. Analysis by thin-layer chromatography showed two substances in the fraction, with retention factors and colors corresponding to those found for 3-oxo-friedelin and epifriedelinol from standard samples. Analysis of this fraction by GC-MS (Figures 1 and 2) confirmed epifriedelinol as the principal constituent and 3-oxofriedelin as the other substance.

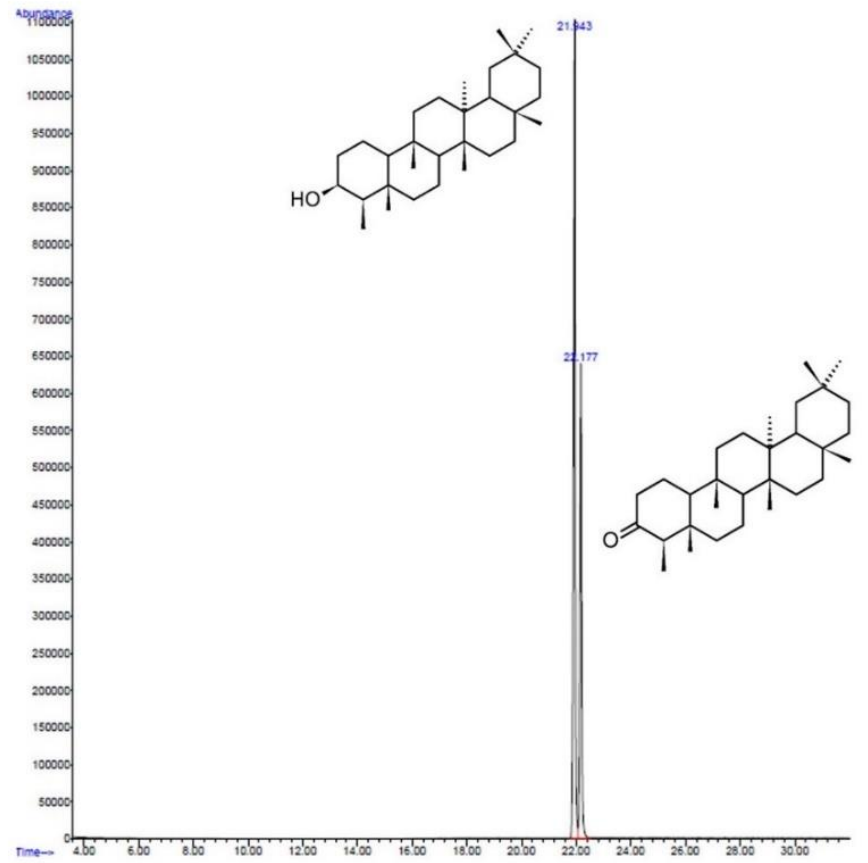

Figure 1. Chromatogram of fraction 9, obtained by column chromatography of a precipitate from the hexane crude extract of leaves of Monteverdia communis, evidencing the peaks of epifriedelinol and 3-oxo-friedelin, with retention times of 21.943 and 22.177 minutes, respectively.

A

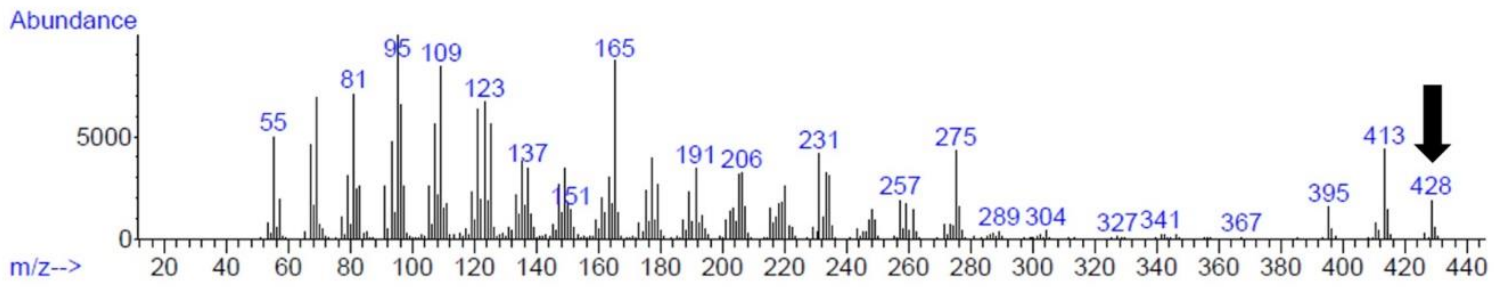

B

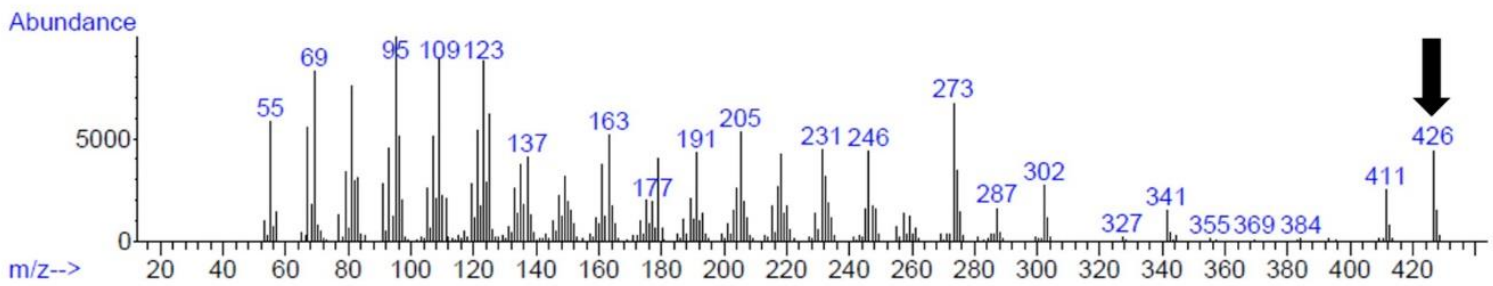

Figure 2. Mass spectra of epifriedelinol (a) and 3-oxo-friedelin (b). Arrows: molecular ions. 


\subsection{Reaction kinetics of antioxidant activity.}

Reaction kinetics with DPPH of fraction 9, hexane and ethanol extracts of leaves and stems, and positive controls BHT and rutin are illustrated in Figure 3.
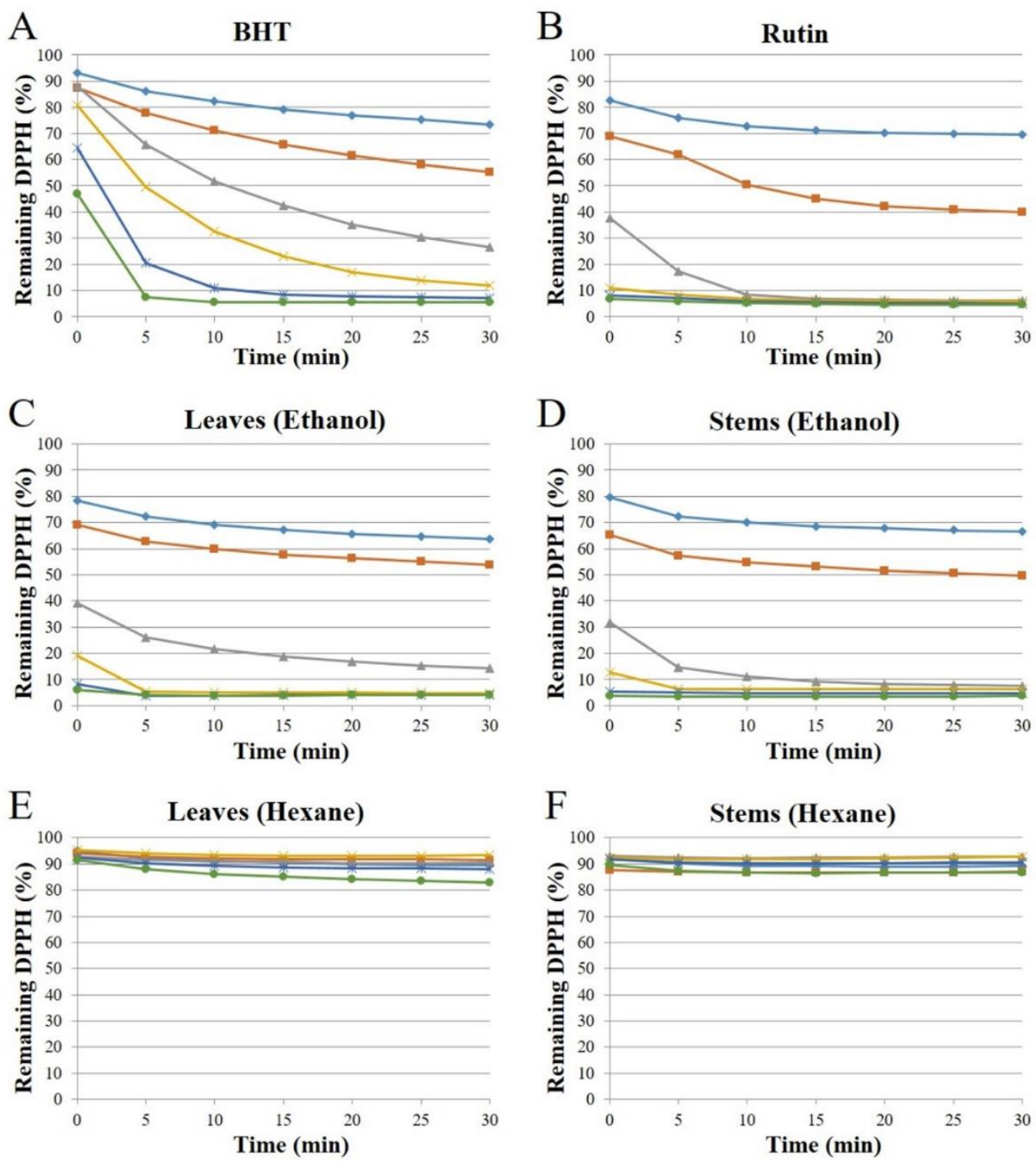

G Fraction 9 (Triterpenes)
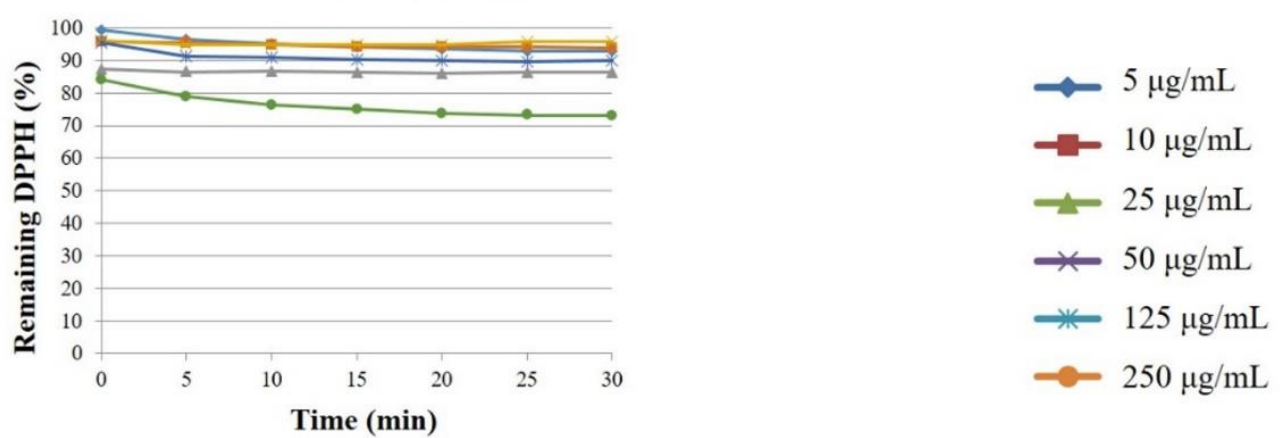

Figure 3. Reaction kinetics of butylated hydroxytoluene (BHT) (a), rutin (b), crude extracts of leaves and stems (c-f) and fraction 9 composed by the triterpenes epifriedelinol and 3-oxo-friedelin (g) from Monteverdia communis, with 1,1-diphenyl2-picrylhydrazyl (DPPH).

Ethanol extract of leaves achieves its maximum antioxidant activity (96\%) at the concentration of $125 \mu \mathrm{g} / \mathrm{mL}$, with $4 \%$ remaining DPPH. Ethanol extract of stems achieves its 
maximum antioxidant activity (97\%) at time zero and $125 \mu \mathrm{g} / \mathrm{mL}$, with $3 \%$ remaining DPPH. BHT and rutin show their maximum antioxidant activity (95\%), respectively, at $250 \mu \mathrm{g} / \mathrm{mL}$ and $25 \mu \mathrm{g} / \mathrm{mL}$, with $5 \%$ remaining DPPH. It is important to highlight that both ethanol extracts showed great antioxidant activity after 5 minutes of reaction, with less than $10 \%$ remaining DPPH at $50 \mu \mathrm{g} / \mathrm{mL}$, demonstrating a better action than BHT $(50 \%)$ at the same time and concentration.

Hexane extracts of leaves and stems, as well as fraction 9, showed low antioxidant activity. Among them, fraction 9 showed the best maximum activity (27\%). This fraction was isolated from hexane extract of leaves, which had a maximum activity of $17 \%$, while stem hexane extract showed a maximum activity of $13 \%$.

\subsection{Total antioxidant activity $\left(E C_{50}\right)$ and flavonoids content.}

Total antioxidant activity ( $\left.\mathrm{EC}_{50}\right)$ of ethanol extracts of leaves and stems of $M$. communis and positive controls and the total flavonoid content in the ethanol extracts are shown in Table 3. The curves obtained by linear regression provided a correlation coefficient $r^{2}>0.80$, and statistical treatment of data by ANOVA did not indicate significant differences among the independent experiments performed for each sample $(p \geq 0.05)$.

The EC50 values of ethanol extracts were significantly lower than BHT's and statistically equivalent to rutin's. It is important to emphasize that the extracts of M. communis are composed of several compounds in small amounts, while BHT and rutin are pure substances. Also, ethanol extracts of leaves and stems did not show significant differences among each other, with similar antioxidant activities in both extracts.

A weak negative correlation (-0.30) between the total flavonoid content in the ethanol extracts and their $\mathrm{EC}_{50}$ was indicated by Pearson's Correlation test, suggesting that the antioxidant activity may be related to the presence of other flavonoids and compounds in the extracts in addition to flavones and flavonols.

Table 3. $\mathrm{EC}_{50}$ values of butylated hydroxytoluene (BHT), rutin and ethanol extracts of leaves and stems of Monteverdia communis, and flavonoids content of these extracts expressed as rutin equivalents.

\begin{tabular}{c|c|c} 
Sample & EC $_{\boldsymbol{5 0}}$ (g sample / g DPPH) \pm SD & \% Flavonoids $\mathbf{\text { SD }}$ \\
\hline BHT & $0.88 \pm 0,09^{\mathrm{a}}$ & - \\
\hline Rutin & $0.47 \pm 0,09^{\mathrm{b}}$ & - \\
\hline Ethanol extract of leaves & $0.59 \pm 0,08^{\mathrm{b}}$ & $4.77 \pm 0.24$ \\
\hline Ethanol extract of stems & $0.56 \pm 0,10^{\mathrm{b}}$ & $5.80 \pm 0.59$
\end{tabular}

$\mathrm{EC}_{50}$, concentration of the sample required to reduce the initial concentration of DPPH in 50\%; SD, Standard Deviation; a-b, Equal letters indicate that according to the Tukey-Kramer test, there is no significant difference between values in the same column

\subsection{Phytochemical screening.}

Crude extracts of $M$. communis were submitted for phytochemical screening and results are shown in Table 4. The test for triterpenes and steroids provided a strong positive result for triterpenes, whose high concentrations may have disguised the presence of steroids. The negative result for flavonoids may be due to the low sensitivity of the methodology used in the phytochemical screening, given that the flavonoids content was quantified in the spectrophotometric analysis. 
Table 4. Chemical classes tested in crude extracts of Monteverdia communis.

\begin{tabular}{|c|c|c|c|c|}
\hline $\begin{array}{c}\text { Chemical } \\
\text { Class } \\
\end{array}$ & $\begin{array}{c}\text { Hexane Extract } \\
\text { of Leaves }\end{array}$ & $\begin{array}{c}\text { Hexane Extract } \\
\text { of Stems }\end{array}$ & $\begin{array}{c}\text { Ethanol Extract } \\
\text { of Leaves }\end{array}$ & $\begin{array}{c}\text { Ethanol Extract } \\
\text { of Stems }\end{array}$ \\
\hline Phenolic compounds & - & - & + & + \\
\hline Flavonoids & - & - & - & - \\
\hline Tannins & ++ & + & ++ & ++ \\
\hline Anthraquinones & - & - & ++ & ++ \\
\hline Coumarins & + & + & + & + \\
\hline Saponins & - & - & + & + \\
\hline Triterpenoids & ++ & ++ & ++ & ++ \\
\hline Alkaloids & + & - & - & - \\
\hline
\end{tabular}

\subsection{Discussion.}

The concurrent occurrence of the pentacyclic triterpenes epifriedelinol and friedelin was described in other species of the genus Monteverdia, besides $M$. communis, such as $M$. aquifolia, M. ilicifolia and Monteverdia macrocarpa (Ruiz \& Pav.) Biral in the leaves [31-33] and Monteverdia truncata (Nees) Reiss. in branches [34]. Triterpenes are considered chemosystematic markers of Maytenus s.l. due to their great occurrence and structure diversity, friedelanes are among the most expressive types [9].

Epifriedelinol was the major component of the precipitated crystals from the hexane extract of leaves of $M$. communis. This compound has several pharmacological properties described in the literature, such as antiulcerogenic [31], antitumor [35,36], antinociceptive [37], protective of traumatic brain injury in rats [38] and antibacterial [39].

Friedelin, the other compound present in the precipitated crystals, is the friedelane triterpene with greater occurrence in Maytenus s.l. [9]. This compound shows antiulcerogenic [31], antinociceptive [37], anti-inflammatory, antipyretic [40], antimicrobial [41], hypolipidemic [42], antidiabetic [43] and cytotoxic activities [44]. It was isolated as one of the major components of the hexane extract of the leaves from M. obtusifolia [45]. Besides, friedelin is the precursor of the quinonemethide triterpenes maytenin and pristimerin, which accumulate in the root barks of Celastraceae species [32] and show antifungal and anticancer properties [46-48].

Potent in vitro and in vivo antioxidant activity of friedelin was demonstrated by Sunil et al. (2013) [49]. In in vitro study, the free radical scavenging assay of friedelin and BHT on DPPH showed their maximum antioxidant activity around $70 \%$, while other in vitro and in vivo assays confirm the antioxidant effect, using different positive controls such as BHT, vitamin $\mathrm{C}$, and curcumin. In the present study, a low antioxidant activity was verified in the fraction containing this triterpenoid. However, $\mathrm{Ng}$ et al. (2003) [50] reported that epifriedelinol, the major component of this fraction, fails to exhibit antioxidant activity and attributes it to the lack of aromatic hydroxyl groups in its chemical structure, just as friedelin [49].

The evaluation of the antioxidant activity showed a great indication of the production of substances with this effect in the ethanol extracts of $M$. communis. Though the leaves are considered the herbal drug in the genus Monteverdia [10,51], the antioxidant activity of the ethanol extract of stems in $M$. communis was statistically similar to the leaves, suggesting that both organs represent promising targets in search of bioactive compounds.

Flavonoids and other phenolic derivatives can capture and neutralize free radical species acting by synergism with other antioxidants [16,52]. The weak negative correlation between $\mathrm{EC}_{50}$ and flavones and flavonols content in $M$. communis suggests that this action may 
also be related to other metabolites in the extracts. In addition to flavones and flavonols, different classes of flavonoids may not be quantified with the methodology performed in this work. In Maytenus s.l, several other flavonoid classes were already described, such as flavanols, which include catechins and proanthocyanidins [53]. All of these substances may be contributing to the excellent antioxidant activity observed for the ethanol extracts.

According to the phytochemical screening of M. communis (Table 3), tannins represent one of the main chemical classes present in the extracts evaluated, besides the triterpenoids. Tannins' action in treating diseases is linked to their free radical scavenging activity [54]. Pessuto et al. (2009) [15] isolated five condensed tannins from leaves of M. ilicifolia, which demonstrated a significant antioxidant activity directly proportional to the number of phenolic hydroxyls present in the chemical structure.

The presence of alkaloids was detected in the hexane extract of the leaves of $M$. communis. Their presence in the genus has been widely described as sesquiterpene alkaloids, occurrring in M. aquifolia [55], Monteverdia chiapensis (Lundell) Biral [56], and M. ilicifolia [57]. These compounds have pharmacological properties already described in the literature, such as antiprotozoal and insecticidal [56,57].

Anthraquinones, coumarins and saponins were detected in extracts of $M$. communis, but not reported in other species of Monteverdia [53]. These chemical classes are relevant components of many herbal drugs used in traditional medicine and show a range of pharmacological activities, such as anticancer [58-60].

\section{Conclusions}

Identifying epifriedelinol and 3-oxo-friedelin as the major components in the hexane extract of the leaves of $M$. communis allows the indication of this species as an outstanding source of bioactive terpenoids. The strong antioxidant activity verified in ethanolic extracts suggests $M$. communis as a promising target for further studies to isolate and identify substances responsible for this effect. The phytochemical screening of hexane and ethanol extracts corroborated other studies already described in the literature and evidenced the presence of different metabolites, providing data for quality control.

\section{Funding}

The first author was a scholarship holder by CNPq - Brazil (PIBIC CNPq/UFF 2013/2014) and FAPERJ (E-26/ 200.925/2014). This study was financed in part by the Coordenação de Aperfeiçoamento de Pessoal de Nível Superior - Brasil (CAPES) - Finance Code 001.

\section{Acknowledgments}

The authors thank Plataforma Analítica da Fundação Oswaldo Cruz (Fiocruz) for their assistance with GC-MS.

\section{Conflicts of Interest}

The authors declare no conflict of interest. 


\section{References}

1. Lietava, J. Medicinal plants in a Middle Paleolithic grave Shanidar IV? J. Ethnopharmacol. 1992, 35, 263266, https://doi.org/10.1016/0378-8741(92)90023-k.

2. Jadhav, C.A.; Vikhe, D.N.; Jadhav, R.S. Global and domestic market of herbal medicines: A review. Research J. Science and Tech. 2020, 12, 327-330, https://doi.org/10.5958/2349-2988.2020.00049.2.

3. Scheffer, M.C. Uso tradicional e atual de espécies de Maytenus. In Conservação e uso sustentável de plantas medicinais e aromáticas: Maytenus spp., espinheira-santa, 2nd ed; Reis, M.S., Silva, S.R., Eds.; IBAMA: Brasília, Brazil, 2004; 53-66.

4. Brazil. Política e Programa Nacional de Plantas Medicinais e Fitoterápicos. Ministério da Saúde: Brasília, Brazil, 2016; $190 . \quad$ Available online: http://bvsms.saude.gov.br/bvs/publicacoes/politica_programa_nacional_plantas_medicinais_fitoterapicos.p df (accessed on 6 May 2021).

5. McKenna, M.J.; Simmons, M.P.; Bacon, C.D.; Lombardi, J.A. Delimitation of the segregate genera of Maytenus s. l. (Celastraceae) based on 40 morphological and molecular characters. Syst. Bot. 2011, 36, 922932, https://doi.org/10.1600/036364411X604930.

6. Biral, L.; Simmons, M.P.; Smidt, E.C.; Tembrock, L.R.; Bolson, M.; Archer, R.H.; Lombardi, J.A. Systematics of New World Maytenus (Celastraceae) and a new delimitation of the genus. Syst Bot. 2017, 42, 1-14, https://doi.org/10.1600/036364417X696456.

7. BFG. Brazilian Flora 2020: innovation and collaboration to meet Target 1 of the Global Strategy for Plant Conservation (GSPC). Rodriguésia 2018, 69, 1513-1527, https://doi.org/10.1590/2175-7860201869402.

8. Biral, L.; Lombardi, J.A. Celastraceae In Flora do Brasil 2020. Jardim Botânico do Rio de Janeiro: Rio de Janeiro, Brazil, 2020. Available online: http://floradobrasil.jbrj.gov.br/reflora/floradobrasil/FB604473 (accessed on 6 May 2021).

9. Guimarães, L.D.; Amaral, F.M.; Santos, N.B.D.; Joffily, A.; Anholeti, M.C.; Paiva, S.R.D. A chemophenetic study of the genus Maytenus s.l. (Celastraceae): contribution to the rational search of its bioactive metabolites. Rodriguésia 2020, 71, e01142019, https://doi.org/10.1590/2175-7860202071055.

10. Brazil. Formulário de Fitoterápicos, Farmacopeia Brasileira, 2nd ed. Anvisa: Brasília, Brazil, $2021 ; 217$. Available online: https://www.gov.br/anvisa/pt-br/assuntos/farmacopeia/formulariofitoterapico/arquivos/2021-fffb2-final-c-capa2.pdf (accessed on 6 May 2021).

11. Tonin, S.T.; Lucas, D.C.; Radunz, A.F.O.; Gilson, Í.K.; Dal Magro, J.; Radunz, M.; Bizollo, A.R.; Radunz, A.L. Feiras Livres: Um Estudo de Caso Relacionado à Disponibilidade de Plantas Medicinais, Aromáticas e Condimentares. Acta Ambient. Catarin. 2020, 17, 1-9, https://doi.org/10.24021/raac.v17i1.5266.

12. Amaral, F.M.; Monteiro, S.S.R.; Leitão, J.C.P.; Paiva, S.R.; Joffily, A. Analysis of labels of medicinal teas from formal trade and notes on the lack of concern for botanical nomenclature Res., Soc. Dev. 2020, 9 , e435997346, https://doi.org/10.33448/rsd-v9i9.7346.

13. Amaral, F.M.; Monteiro, S. S. R.; Fernandes, T.; Teixeira, D.F.; Lucchetti, L.; Jacob, S.C.; Paiva, S.R.; Joffily, A. Pharmacobotanical characterization of Monteverdia ilicifolia (Mart. ex Reiss.) Biral leaves and its adulterants sold as medicinal tea in Brazil: a contribution to quality control. Bol. Latinoam. Caribe Plantas Med. Aromát. 2021, 20, 386-393, https://doi.org/10.37360/blacpma.21.20.4.28.

14. Vellosa, J.C.R.; Khalil, N.M.; Formenton, V.A.F.; Ximenes, V.F.; Fonseca, L.M.; Furlan, M.; Brunetti, I.L.; Oliveira, O.M. Antioxidant activity of Maytenus ilicifolia root bark. Fitoterapia 2006, 77, 243-244, https://doi.org/10.1016/j.fitote.2006.02.007.

15. Pessuto, M.B.; Costa, I.C.; Souza, A.B.; Nicoli, F.M.; Mello, J.C.P.; Petereit, F.; Luftmann, H. Atividade antioxidante de extratos e taninos condensados das folhas de Maytenus ilicifolia Mart. ex Reiss. Quím. Nova. 2009, 32, 412-416, https://doi.org/10.1590/S0100-40422009000200027.

16. Gulcin, I. Antioxidants and antioxidant methods: an updated overview. Arch. Toxicol. 2020, 94, 651-715, https://doi.org/10.1007/s00204-020-02689-3.

17. Vellosa, J.C.R.; Barbosa, V.F.; Khalil, N.M.; Santos, V.A.F.F.M.; Furlan, M.; Brunetti, I.L.; Oliveira, O.M.M.F. Profile of Maytenus aquifolium action over free radicals and reactive oxygen species. Rev. Bras. Cienc. Farm. 2007, 43, 447-453, https://doi.org/10.1590/S1516-93322007000300013.

18. Chiapetti, T.P.; Malavasi, U.C.; Braga, G.C.; Malavasi, M.M.. Effects of the extraction method and chromatographic separation solvent in the antioxidant activity of different species of "espinheira-santa". $J$. Food Sci. Technol. 2019, 56, 5056-5062, https://doi.org/10.1007/s13197-019-03978-1. 
19. Schwanz, M.; Dresch, R.R.; Manfredini, V.; Henriques, A.T. Antioxidative effects of Maytenus dasyclada Mart. (Celastraceae). Int. J. Pharma. Bio. Sci. 2013, 4, 957-969.

20. Silva, G.D.F.; Silva, S.R.S.; Barbosa, L.C.A.; Duarte, L.P.; Ribeiro, S.M.R.; Queiroz, J.H.; Vieira Filho, A.S.; Oliveira, M.L.R. Antioxidant activity of Maytenus imbricata Mart., Celastraceae. Rev. Bras. Farmacogn. 2009, 19, 530-536, https://doi.org/10.1590/S0102-695X2009000400004.

21. Bruni, R.; Rossi, D.; Muzzoli, M.; Romagnoli, C.; Paganetto, G.; Besco, E.; Choquecillo, F.; Peralta, K.; Lora, W.S.; Sacchetti, G. Antimutagenic, antioxidant and antimicrobial properties of Maytenus krukovii bark. Fitoterapia 2006, 77, 538-545, https://doi.org/10.1016/j.fitote.2006.06.009.

22. de Araújo, D.I.; Lima Arruda Fernandes, A.P.; Vieira Pinheiro, A.A.; Souto, A.L.; Sales, K.A.; Fernandes de Araújo, P.R.; de Andrade, R.S.; da Silva, M.S. Determination of flavan-3-ols by high-performance liquid chromatography-photodiode array, antioxidant potential, antimicrobial activity, and pharmacognostic evaluation of Maytenus obtusifolia (Mart.) leaves. Phcog. Res. 2020, 12, 313-321, https://doi.org/10.4103/pr.pr_9_20.

23. Perecin, M.B.; Steenbock, W.; Reis, M.S. Genética de populações de espinheira-santa. In Conservação e uso sustentável de plantas medicinais e aromáticas: Maytenus spp., espinheira-santa, 2nd ed; Reis, M.S., Silva, S.R., Eds.; IBAMA: Brasília, Brazil, 2004; 115-144.

24. Steenbock, W.; Reis, M.S. Manejo de populações naturais de espinheira-santa. In Conservação e uso sustentável de plantas medicinais e aromáticas: Maytenus spp., espinheira-santa, 2nd ed; Reis, M.S., Silva, S.R., Eds.; IBAMA: Brasília, Brazil, 2004; 145-161.

25. Mossi, A.J.; Cansian, R.L.; Leontiev-Orlov, O.; Cechet, J.L.; Carvalho, A.Z.; Toniazzo, G.; Echeverrigaray, S. Diversidade genética de conservação em populações nativas de Maytenus ilicifolia Mart. ex Reiss. Braz. J. Biol. 2009, 69, 447-453, https://doi.org/10.1590/S1519-69842009000200030

26. Carvalho-Okano, R.D.; Leitão Filho, H.D.F. O gênero Maytenus Mol. emend. Mol.(Celastraceae) no Brasil extra-amazônico. In Conservação e uso sustentável de plantas medicinais e aromáticas: Maytenus spp., espinheira-santa, 2nd ed; Reis, M.S., Silva, S.R., Eds.; IBAMA: Brasília, Brazil, 2004; 12-51.

27. Joffily, A.; Vieira, R.C. Anatomia foliar de Maytenus Mol. emend Mol. (Celastraceae), ocorrente no Estado do Rio de Janeiro, Brasil. Acta Bot. Bras. 2005, 19, 549-561, https://doi.org/10.1590/S010233062005000300016.

28. Silva, M.C.A. Produtos do Metabolismo Especial de Clusia fluminensis Planch. \& Triana. Master's Degree, Universidade Federal Fluminense, Niterói, 2011.

29. Silva, M.C.A.; Paiva, S.R. Antioxidant activity and flavonoid content of Clusia fluminensis Planch. \& Triana. An. Acad. Bras; Ciênc. 2012, 84, 609-616, https://doi.org/10.1590/S0001-37652012000300004.

30. Matos, F.J. Introdução à Fitoquímica Experimental, 2nd ed.; Edições UFC: Fortaleza, Brazil, $1997 ; 141$.

31. Queiroga, C.L.; Silva, G.F.; Dias, P.C.; Possenti, A.; Carvalho, J.E. Evaluation of the antiulcerogenic activity of friedelan-3 $\beta$-ol and friedelin isolated from Maytenus ilicifolia (Celastraceae). J. Ethnopharmacol. 2000, 72, 465-468, https://doi.org/10.1016/s0378-8741(00)00237-3.

32. Corsino, J.; Carvalho, P.R.; Kato, M.J.; Latorre, L.R.; Oliveira, O.M.; Araújo, A.R.; Bolzani, V.D.; França, S.C.; Pereira, A.M.; Furlan, M. Biosynthesis of friedelane and quinonemethide triterpenoids is compartmentalized in Maytenus aquifolium and Salacia campestris. Phytochemistry 2000, 55, 741-748, https://doi.org/10.1016/S0031-9422(00)00285-5.

33. Malaník, M.; Treml, J.; Rjašková, V.; Tížková, K.; Kaucká, P.; Kokoška, L.; Kubatka, P.; Šmejkal, K. Maytenus macrocarpa (Ruiz \& Pav.) Briq.: Phytochemistry and Pharmacological Activity. Molecules 2019, 24, 2288, https://doi.org/10.3390/molecules24122288.

34. Salazar, G.D.M.; Duarte, L.P.; Vieira-Filho, A.S.; Silva, G.D.F.; Lula, I.S. Maytenus truncata Reiss. Chemical Constituents. Eur. J. Pharm. Sci. 2001, 13, S105.

35. Kundu, J.K.; Rouf, A.S.S.; Hossain, M.D.N.; Hasan, C.M.; Rashid, M.A. Antitumor activity of epifriedelanol from Vitis trifolia. Fitoterapia. 2000, 71, 577-579, https://doi.org/10.1016/s0367-326x(00)00191-x.

36. Yang, J.; Fa, J.; Li, B. Apoptosis induction of epifriedelinol on human cervical cancer cell line. Afr. J. Tradit. Complement. Altern. Med. 2017, 14, 80-86, https://doi.org/10.21010/ajtcam.v14i4.10.

37. Salama, A.M.; Gamboa, S.; Buitrago, G. Antinociceptive activity of triterpenes isolated from Clusia ellipticifolia. Rev. Colomb. Cienc. Quím. Farm. 2004, 33, 156-162. Available online: https://revistas.unal.edu.co/index.php/rccquifa/article/view/1657 (accessed on 6 May 2021).

38. Li, S.; Zhang, Q.; Li, P. Protective effects of epifriedelinol in a rat model of traumatic brain injury assessed with histological and hematological markers. Transl. Neurosci. 2018, 9, 38-42, https://doi.org/10.1515/tnsci2018-0008. 
39. Kannathasan, K.; Senthilkumar, A.; Venkatesalu, V. Crystal structure and antibacterial evaluation of epifriedelinol isolated from Vitex peduncularis Wall. ex Schauer. Arab. J. Chem. 2019, 12, 2289-2292, https://doi.org/10.1016/j.arabjc.2015.02.013.

40. Antonisamy, P.; Duraipandiyan, V.; Ignacimuthu, S. Anti-inflammatory, analgesic and antipyretic effects of friedelin isolated from Azima tetracantha Lam. in mouse and rat models. J. Pharm. Pharmacol. 2011, 63, 1070-1077, https://doi.org/10.1111/j.2042-7158.2011.01300.x.

41. Kuete, V.; Nguemeving, J.R.; Beng, V.P.; Azebaze, A.G.; Etoa, F.X.; Meyer, M.; Bodo, B.; Nkengfack, A.E. Antimicrobial activity of the methanolic extracts and compounds from Vismia laurentii De Wild (Guttiferae). J. Ethnopharmacol. 2007, 109, 372-379, https://doi.org/10.1016/j.jep.2006.07.044.

42. Duraipandiyan, V.; Al-Dhabi, N.A.; Irudayaraj, S.S.; Sunil, C. Hypolipidemic activity of friedelin isolated from Azima tetracantha in hyperlipidemic rats. Rev. Bras. Farmacogn. 2016, 26, 89-93, https://doi.org/10.1016/j.bjp.2015.07.025.

43. Sunil, C.; Irudayaraj, S.S.; Duraipandiyan, V.; Alrashood, S.T.; Alharbi, S.A.; Ignacimuthu, S. Friedelin exhibits antidiabetic effect in diabetic rats via modulation of glucose metabolism in liver and muscle. $J$. Ethnopharmacol. 2021, 268, 113659, https://doi.org/10.1016/j.jep.2020.113659.

44. Subash-Babu, P.; Li, D.K.; Alshatwi, A.A. In vitro cytotoxic potential of friedelin in human MCF-7 breast cancer cell: Regulate early expression of Cdkn2a and pRb1, neutralize mdm2-p53 amalgamation and functional stabilization of p53. Exp. Toxicol. Pathol. 2017, 69, 630-636, https://doi.org/10.1016/j.etp.2017.05.011

45. Silva MS, Sousa DP, Medeiros VM, Folly MAB, Tavare JF, Barbosa-Filho JM. Alkaloid, flavonoids, and pentacyclic triterpenoids of Maytenus obtusifolia Mart. Biochem. Syst. Ecol. 2008, 36, 500-503, https://doi.org/10.1016/j.bse.2008.01.006.

46. Gullo, F.P.; Sardi, J.C.; Santos, V.A.; Sangalli-Leite, F.; Pitangui, N.S.; Rossi, S.A.; De Paula e Silva, A.C.A.; Soares, L.A.; Silva, J. F.; Oliveira, H.C.; Furlan, M.; Silva, D.H.; Bolzani, V.S.; Mendes-Giannini, M.J.; Fusco-Almeida, A.M. Antifungal activity of maytenin and pristimerin. Evid. Based Complement. Alternat. Med. 2012, 2012, 340787, https://doi.org/10.1155/2012/340787.

47. Yousef, B.A.; Hassan, H.M.; Zhang, L.Y.; Jiang, Z.Z. Anticancer potential and molecular targets of pristimerin: a mini-review. Curr. Cancer Drug Targets 2017, 17, 100-108, https://doi.org/10.2174/1568009616666160112105824.

48. Hernandes, C.; Miguita, L.; de Sales, R.O.; Silva, E.P.; Mendonça, P.O.R.; Lorencini da Silva, B.; Klingbeil, M.F.G.; Mathor, M.B.; Rangel, E.B.; Marti, L.C.; Coppede, J.S.; Nunes, F.D.; Pereira, A.M.S.; Severino, P. Anticancer Activities of the Quinone-Methide Triterpenes Maytenin and 22- $\beta$-hydroxymaytenin Obtained from Cultivated Maytenus ilicifolia Roots Associated with Down-Regulation of miRNA-27a and miR20a/miR-17-5p. Molecules 2020, 25, 760, https://doi.org/10.3390/molecules25030760.

49. Sunil, C.; Duraipandiyan, V.; Ignacimuthu, S.; Al-Dhabi, N.A. Antioxidant, free radical scavenging and liver protective effects of friedelin isolated from Azima tetracantha Lam. leaves. Food Chem. 2013, 139, 860-865, https://doi.org/10.1016/j.foodchem.2012.12.041.

50. Ng, T.B.; Liu, F.; Lu, Y.; Cheng, C.H.K.; Wang, Z. Antioxidant activity of compounds from the medicinal herb Aster tataricus. Comp. Biochem. Physiol. C. Toxicol. Pharmacol. 2003, 136, 109-115, https://doi.org/10.1016/s1532-0456(03)00170-4.

51. Brazil. Farmacopeia Brasileira, 6th ed., Volume II: Monografias, Plantas Medicinais. Anvisa: Brasília, Brazil, 2019. Available online: https://www.gov.br/anvisa/pt-br/assuntos/farmacopeia/farmacopeiabrasileira/arquivos/7989json-file-1 (accessed on 6 May 2021).

52. Karak, P. Biological activities of flavonoids: an overview. Int. J. Pharm. Sci. \& Res. 2019, 10, 1567-1574, https://doi.org/10.13040/IJPSR.0975-8232.10(4).1567-74.

53. Zhang, L.; Ji, M.Y.; Qiu, B.; Li, Q.Y.; Zhang, K.Y.; Liu, J.C.; Dang, L.S.; Li, M.H. Phytochemicals and biological activities of species from the genus Maytenus. Med. Chem. Res. 2020, 29, 575-606, https://doi.org/10.1007/s00044-020-02509-4.

54. Hussain, G.; Huang, J.; Rasul, A.; Anwar, H.; Imran, A.; Maqbool, J.; Razzaq, A.; Aziz, N.; Makhdoom, E.u.H.; Konuk, M.; Sun, T. Putative Roles of Plant-Derived Tannins in Neurodegenerative and Neuropsychiatry Disorders: An Updated Review. Molecules 2019, 24, 2213, https://doi.org/10.3390/molecules24122213.

55. Corsino, J.; Bolzani, V.S.; Pereira, M.A.S.; França, S.C.; Furlan, M. Bioactive sesquiterpene pyridine alkaloids from Maytenus aquifolium. Phytochemistry 1998, 48, 137-140, https://doi.org/10.1016/S00319422(97)00824-8. 
56. Núñez, M; Guadaño, A.; Jiménez, I.A.; Ravelo, A.G.; González-Coloma, A.; Bazzocchi, I.L. Insecticidal Sesquiterpene Pyridine Alkaloids from Maytenus chiapensis. J. Nat. Prod. 2004, 67, 14-18, https://doi.org/10.1021/np030347q.

57. Santos, V.A.F.F.M.; Regasini, L.O.; Nogueira, C.R.; Passerini, G.D.; Martinez, I.; Bolzani, V.S.; Graminha, M.A.S.; Cicarelli, R.M.B.; Furlan, M. Antiprotozoal Sesquiterpene Pyridine Alkaloids from Maytenus ilicifolia. J. Nat. Prod. 2012, 75, 991-995, https://doi.org/10.1021/np300077r.

58. Wang, D.; Wang, X.-H.; Yu, X.; Cao, F.; Cai, X.; Chen, P.; Li, M.; Feng, Y.; Li, H.; Wang, X. Pharmacokinetics of Anthraquinones from Medicinal Plants. Front. Pharmacol. 2021, 12, 638993, https://doi.org/10.3389/fphar.2021.638993.

59. Küpeli Akkol, E.; Genç, Y.; Karpuz, B.; Sobarzo-Sánchez, E.; Capasso, R. Coumarins and Coumarin-Related Compounds in Pharmacotherapy of Cancer. Cancers 2020, 12, 1959, https://doi.org/10.3390/cancers12071959.

60. Rehan, M.; Shafiullah; Mir, S.A. Structural diversity, natural sources, and pharmacological potential of plantbased saponins with special focus on anticancer activity: a review. Med. Chem. Res. 2020, 29, 1707-1722, https://doi.org/10.1007/s00044-020-02600-w. 